\title{
Corruption and Resource Allocation: Evidence from China
}

\author{
By: Wei $\mathrm{Li}$ \\ William Davidson Working Paper Number 396 \\ June 2001
}




\title{
Corruption and Resource Allocation: Evidence from China
}

\author{
Wei $\mathrm{Li}^{1}$ \\ Darden School of Business \\ University of Virginia \\ Charlottesville, VA 22906-6550 \\ E-mail: LiW@darden.virginia.edu
}

Tel: (434)243-7691

Fax: (434)243-7681

June 2001

\footnotetext{
${ }^{1}$ I have benefited from suggestions from Roger Gordon, Gary Jefferson, Steven Levitt, Mike Moore, Barry Naughton, Jeff Nugent, Yingyi Qian, Susan Rose-Ackerman, Andrei Shleifer, Ted Snyder, Gordon Tullock, an anonymous referee, workshop participants in Yale, USC, Michigan, and Maryland, and participants in the Corrupt Exchanges Conference at ZiF, Universität Bielefeld, Germany in May 2001, and in the 2001 Davidson Institute-CEPR International Conference on Transition Economics in Portoroz, Slovenia, in June 2001. I am also grateful to Junfeng Qi and Yang Yu for research assistance. This project received funding from the Fuqua School of Business, Duke University, and from the Darden School Foundation, University of Virginia.
} 


\begin{abstract}
Exploiting a unique data set containing transactions data from a panel of 769 Chinese stateowned enterprises between 1980 and 1989, this paper tests microeconomic implications of a pervasive form of corruption - official diversion of under-priced, in-plan goods to the market. Corruption has the predicted effects on resource allocation. Official under-pricing of in-plan goods, which lowers the marginal cost of diversion, increases the procurement of output into the plan for the purpose of diversion. Market competition introduced by allowing firms to sell directly to the market appears to reduce corruption and therefore lessen its distortions.
\end{abstract}

JEL classification: L51, L12, P21

Keywords: Corruption, resource allocation, China, dual-track system 


\section{Introduction}

Shleifer and Vishny (1993) define corruption as the sale of government-produced goods or services by public officials for private gain. They argue that corruption is distortionary and detrimental to economic development. Indeed corruption is thought to be particularly pervasive in transition and developing economies. ${ }^{1}$ Using available cross-country aggregate data, recent empirical work (e.g., Mauro (1995) and Wei (2000)) confirms a link between higher perceived corruption and lower investment and growth. However, studies using aggregate data cannot analyze the behavioral implications of corruption models, ${ }^{2}$ nor examine the microeconomic mechanisms by which corruption distorts resource allocation.

Empirical analysis of the microeconomics of corruption can shed considerable light on the economic nature of corrupt practices - the linkage between bureaucratic control and corruption (Rose-Ackerman, 1999), and the impact of corruption on resource allocation. It can also guide policies that may limit corruption and lessen its distortions. But collecting microeconomic data on corrupt transactions is itself a tall order. Fortunately, micro data that objectively document some aspects of corruption are available from a survey of Chinese state-owned enterprises operating under China's dual-track (plan/market) system. Under this system, a specific form of corruption - the diversion by officials of under-priced in-plan resources to outside-plan customers - was pervasive.

The usefulness of the data owes much to the experimental nature of the Chinese economic reforms. Before full implementation of the "dual-track" system, official diversion thrived, even in the absence of a formal product market. It was not uncommon for a corrupt official who controlled the in-plan allocation to divert under-priced in-plan goods to outside-plan customers in exchange for favors and in-kind gifts (e.g., "back door" access to scarce consumer goods). ${ }^{3}$ But the implicit outside-plan prices at which the diverted in-plan goods were soldkey variables influencing corrupt transactions - were unobservable. The introduction of the

\footnotetext{
${ }^{1}$ According to the widely used Corruption Perception Index published by Transparency International (2000) for 90 economies around the world, economies that are considered more corrupt than the median are all developing and transition economies. This index is compiled based on a "poll of polls" drawing upon numerous distinct surveys of (non-domestic) expert and general public views of the extent of corruption.

${ }^{2}$ Rose-Ackerman (1998, p. 36) argues that "[t]o go beyond macroeconomic findings it is necessary to isolate the structural features that create incentives for corrupt behavior."

${ }^{3}$ While accepting cash bribes was considered a crime in China, receiving most of the in-kind payoffs was not. Without an anonymous product market offering luxury consumer goods on which corrupt officials could spend their illicit incomes, cash bribes were less valuable than in-kind bribes. It is not surprising that corruption was not considered a pervasive problem before 1979 when the reforms started.
} 
dual-track system altered the environment of official diversion. Under the new system, a stateowned firm was no longer a passive production unit that turned over its entire output to the plan. After fulfilling its plan obligations, the firm under the dual-track system could produce extra outside-plan output and sell it directly to customers at a "floating" or market price. The government regulated the "floating prices" initially, but liberalized the prices on outside-plan transactions on January 1, 1985. The dual-track system thus created a formal product market parallel to planning. Corrupt officials could and allegedly did divert under-priced in-plan goods that they controlled from the plan and sold them on the product markets at higher market prices after 1985. The uniqueness of the data is that both in-plan quotas that state-owned firms faced and indexes of the plan prices and the market prices that the corrupt officials faced are observed.

Using this dataset, I address the following questions in this study: How did corruption affect the allocation of in-plan resources (i.e., the setting of output and input quotas that firms faced) and outside-plan resources? How did the introduction of market competition change corruption, and its impact on resource allocation?

Given the specific nature of the economic institutions in China, I briefly describe in Section 2 the dual-track system and official diversion. To derive testable implications regarding official diversion in China, I then extend Shleifer and Vishny's (1993) model of corruption in Section 3. Shleifer and Vishny show that a corrupt official will behave as a bribe-maximizing monopolist if he can restrict the supply of a government-produced good. In the case without theft, the official turns over the official plan price for that good to the government. A decrease in the plan price, which lowers the official's marginal cost of corruption, increases corruption. The marginal cost of producing the good is immaterial to the official as the cost is borne by the government. This model corresponds closely to the situation in China.

There is, however, an important difference in the underlying institutions. In Shleifer and Vishny (1993), the producer is passive. Under China's dual-track system, the state-owned firm can sell its outside-plan output directly in the market after it has fulfilled its in-plan output quota set by the official. As a result, a corrupt official (distinct from the firm) who diverts in-plan goods would face product market competition from the firm and possibly other competitors. A decrease in the plan price still increases corruption. But other predictions differ. In particular, while the marginal cost of production remains immaterial to the corrupt official, an increase in marginal cost may cause the firm to raise output price in the market, thereby widening the gap between market and plan prices. The resulting increase in the net 
marginal benefit of diversion may then induce the official to increase the procurement of quotas for the purpose of diversion. Product market competition introduced by allowing state firms to sell directly to the market (and by lowering entry barriers for non-state firms (Li, 1997)) will reduce the net marginal benefits of corruption and therefore lessen corruption distortions.

Consistent with these predictions, the empirical results presented in Section 4 reveal that corruption had a significant impact on the allocation of in-plan resources between 1980 and 1989. The procurement of in-plan goods by officials decreases with the plan price and increases with the marginal cost of production. Interestingly, the evidence shows that there is little qualitative difference in how official diversion affected the allocation of in-plan resources before and after the price liberalization in 1985. It thus suggests that official diversion existed before the 1985 price liberalization and that corrupt officials made diversion decisions before 1985 based on the implicit prices that embodied in-kind bribes.

Corruption also had a significant impact on market allocation and was affected by market competition. Output pricing regression models reveal that an increase in the output quota had a negative effect on the market price of output (after controlling for the implied endogeneity of the quota), indicating that the dual-track system changed the industrial organization of official diversion in China. The market competition created by allowing firms to sell directly to the markets where diverted goods are also sold, ceteris paribus, has resulted in lower market prices, higher output, and lower corruption distortions. The evidence reveals that, while the dual-track system provided the fodder for sustaining corruption by maintaining the plan, the competition that it fostered by allowing firms to sell outside-plan output directly to the market (and by lowering entry barriers for non-state firms) appears to have mitigated corruption to some extent.

\section{The Dual-Track System and Corruption}

The dual-track system began its gradual emergence in the late 1970s when the Chinese government allowed state-owned firms to sell outside-plan outputs at "floating prices." Still subject to price control, "floating prices" could not exceed plan prices by more than 20 percent. On January 1, 1985, the government lifted these price controls on outside-plan transactions.

Under the dual-track system, a state-owned firm must deliver its compulsory output quota to a relevant branch of the Material Supply Bureau (MSB) at the plan price. In return, it may receive some in-plan allocation of inputs (i.e., input quotas) at plan input prices. After 
fulfilling its plan obligations, the firm may then produce outside-plan output and sell it to the market. But it must buy any additional material inputs from the market as well. Plan prices continue to be set centrally by the State Price Bureau at levels often substantially lower than market prices. ${ }^{4}$ MSB officials control the allocation of in-plan resources (Byrd, 1992). Given the hierarchical nature of the MSB organization, each state-owned firm may deal with multiple MSB officials with some division of responsibility for particular products and material inputs.

To illustrate how the dual-track system worked in practice, I present in Table 1 some statistics on state-owned enterprises' transactions under the dual-track system. (A brief description of the enterprise survey data is given in the Appendix.) Table 1 shows that the price liberalization in 1985 markedly raised market price inflation. In an effort to combat rising inflation in the late 1980s, the government restricted the increases in plan prices, causing the gap between market and plan prices to widen considerably in the late 1980s. The data also reveal another interesting fact. While the output quota per firm grew by 37 percent in real terms between 1981 and 1990, the amount of input quota delivered to an average sample firm fell by more than 12 percent in real terms. Net contribution of resources to the plan per sample firm (Column 4 minus Column 8) increased from 16.2 to 30.1 million yuan between 1981 and 1989. Given that the sample is quite representative of the Chinese state-owned industry, ${ }^{5}$ state-owned industrial firms appeared to be increasingly significant net contributors to the plan.

Material balance in the plan, however, requires that resources procured from state-owned firms (sources) equal in-plan uses, which comprise resources allocated to in-plan intermediate uses and to in-plan final uses (i.e., consumption, investment, net exports, and changes in inventory). One would thus expect that the net contribution to the plan shown in the data should have been allocated to non-industrial in-plan intermediate uses and to in-plan final uses. Using Chinese input-output tables, Li (2001) finds that even after taking into account possible in-plan non-industrial intermediate uses and final uses, in-plan procurement still exceeded accountable in-plan uses by a significant margin. In other word, there were leakages in the plan: more resources were procured into the plan than were allocated within the plan. The apparent leakages are puzzling.

A plausible explanation, offered by Chinese journalists and economists, and often based on first-hand observations, was that substantial amounts of in-plan goods were diverted out of the

\footnotetext{
${ }^{4}$ Plan prices were determined based on a set of cost-plus rules (see "Wujia Wenjian Xuebian: 1979-1983" (Selected Pricing Regulations), Price Research Institute, State Price Bureau, 1984).

${ }^{5} \mathrm{See} \mathrm{Li} \mathrm{(1994)} \mathrm{and} \mathrm{Li} \mathrm{(1997)} \mathrm{for} \mathrm{more} \mathrm{detailed} \mathrm{discussions} \mathrm{of} \mathrm{the} \mathrm{sample} \mathrm{characteristics}$
} 
plan by officials who sought to capture the rents created by the under-pricing of in-plan goods (Huang, 1996). That is, the leakages in the plan represented "guandao" or official diversion. Browsing Chinese newspapers and magazines published in the late 1980s, one cannot help but notice a growing perception of the pervasiveness of official diversion. A common scheme used by corrupt officials was to create a web of trading companies, otherwise known as "briefcase companies" whose tangible assets (e.g., business cards and company seals) could easily fit into a briefcase. Often these trading companies were affiliated with the MSBs or state-owned firms, and were entitled to distribute in-plan goods. Through repeated self-dealing, i.e., repeatedly selling in-plan goods from one briefcase company to the next for a small markup, a corrupt official could easily raise the price of the in-plan goods to its market clearing level before offloading the goods to users at market or implicit market-clearing prices. Huang (1996, p. 177) reports that in Shenyang the title to a shipment of cold-rolled steel plates was flipped multiple times among briefcase companies before it was delivered to the user, raising the price per ton from 1400 yuan to 7200 yuan.

Since official diversion was illegal, MSB officials often sought protection by bribing law enforcement officers, and the managers whose firms' profits were pillaged by diversion. However, collusion between MSB officials and firm managers was often tenuous. In detailed case studies of manufacturers in China, Byrd (1992, p. 323 and 392) found that the MSB would raise procurement quotas on their outputs when demand for them was strong and force the firms to sell to the market on their own when the demand was weak. Byrd (p. 392) concluded that "[s] upervisory authorities [MSBs] acted largely as self-interested entities promoting their own benefits and protecting their own interests, with little regard for [the producers]." It thus appears that corruption may have played a role in the allocation of in-plan resources.

\section{The Model}

In Shleifer and Vishny's (1993) basic model of corruption, a corrupt official who is the monopoly seller of a government-produced good maximizes bribes by restricting the supply of the good. As depicted in Figure 1, a decrease in the official price, $p$, increases both bribes and the quantity of corrupt sales. But corruption is not affected by the cost of production, which is borne by the government and hence immaterial to the official. Reducing the official's market power by introducing competition reduces corruption distortions.

To test these predictions using the Chinese data, one must consider how the predictions 
are affected by the more complex institutions in China. The discussion in Section 2 suggests that stylized features of the Chinese institutions can be summarized as follows. 1) Output and input quotas are likely set by different officials. The firm under study may face an output official with control rights over the procurement of its output into the plan, and an input official with control rights over the allocation of the firm's in-plan input. 2) Plan prices and base wage rates are determined by the central government, and thus are exogenous to the officials and the firm. 3) Corrupt officials may face competition in the product market, since firms can sell directly to the market. 4) The firm and the officials may not collude perfectly, so their objectives may diverge: while the corrupt officials maximize corruption rents, the firm may be more interested in profits. But if the output officials and the firm collude perfectly so that they jointly maximize corruption rents (and the government picks up any losses or profits that the firm incurs), they should behave in the same way as the monopoly official in Shleifer and Vishny's model. To the extent that Shleifer and Vishny's predictions differ from the implications of corruption under imperfect collusion to be derived below, the hypothesis of imperfect collusion can be tested.

Consider first the simple case of perfectly competitive product markets where both the firm and the officials take the market output price $P$ and the market input price $M$ as given. The firm produces an output using labor and an intermediate input produced by an input producer. The output official procures the output quota $Q$ from the firm at the plan price $p$. The input official allocates the input quota $X$ to the firm at the plan price $m$. Assume that the output official is required under the plan to transfer to the plan a fixed fraction, $1-\delta$, of the output quota $Q$, where $\delta \in(0,1)$, and can divert $\delta Q$ to the market. Similarly, diversion may occur as the input official makes procurement and allocation decisions. Let $Q^{*}$ denote the input official's procurement from the firm's input producer. The input official allocates to the firm $X=\left(1-\delta^{*}\right) Q^{*}$ as its input quota, but can divert $\delta^{*} Q^{*}$ to the market. ${ }^{6}$ The output and input officials' payoffs from diversion can be expressed as

$$
R_{O}=(P-p) \delta Q-C_{O}(\delta Q), \quad R_{I}=(M-m) \delta^{*} Q^{*}-C_{I}\left(\delta^{*} Q^{*}\right)
$$

where $C_{O}(\delta Q)$ and $C_{I}\left(\delta^{*} Q^{*}\right)$ are the total costs of diversion. The costs include expected punishments for corruption, which are expected to be convex. The output and input officials'

\footnotetext{
${ }^{6}$ One can endogenize $\delta$ and $\delta^{*}$ without changing the derived testable implications. Since $\delta$ and $\delta^{*}$ are unobservable, such a generalization is superfluous for the purpose of this paper.
} 
diversion problems are thus symmetrical. Below I focus on discussing the implications of output diversion since the implications of input diversion can be obtained analogously.

In equilibrium, the output official sets the output quota $Q$ to equate the marginal benefit and cost of diversion. The optimal output quota $Q(P, p)$ should increase with $P$ and decrease with $p$, since an increase in $P$ or a decrease in $p$ raises the net marginal benefit from diverting $Q$. But since the cost of production is immaterial to the official, neither $M$ nor the base wage rate that the firm faces, $W$, should affect $Q$. By analogy, the optimal input quota $X(M, m)$, as a fraction of the procurement $Q^{*}$ imposed on the input producer, should increase with $M$ and decrease with $m$. And $X$ should not be affected by the cost of producing the input- the market price of other inputs, $M^{*}$, and the wage rate, $W^{*}$, that the input producer faces. The comparative statics results for $Q$ and $X$ are listed in Columns 1 and 2 in Table 2.

The implications of corruption are different when sellers have market power in the emerging product markets. Given that the officials have the control right over the allocation of in-plan resources, the interaction between the officials and the firm can be modeled as a two-stage game: ${ }^{7}$ The officials set $Q$ and $X$ first, and then the firm names $P$ after observing $Q$ and $X$.

Consider first the firm's pricing decision. Having market power as a seller in the output market, the firm faces a downward sloping residual demand curve $d(P, Q)$ for its outside-plan output. Since diversion and in-plan allocation "steal" some of the firm's customers, $d(P, Q)$ is in general decreasing in $Q$. The firm's profits from meeting both its mandatory output quota $Q$ and its residual market demand $d(P, Q)$ can be written as

$$
\Pi=(P-C) d(P, Q)+(p-C) Q+(M-m) X
$$

where $C=C(M, W)$ is the marginal cost, which increases with $M$ and $W$. The firm, maximizing $\Pi$, sets its optimal price to equate the marginal revenue from market sales and the marginal cost of production, ${ }^{8}$ as shown in Panel A, Figure 2. The optimal price, $P(Q, M, W)$, should in general be a function that decreases with $Q$ and increases with the marginal cost of production, i.e., $M$ and $W$. This is intuitive. By increasing $Q$, the official "steals" some additional customers from the firm and thus limits the firm's market power and its ability

\footnotetext{
${ }^{7}$ This implicitly assumes that the officials can credibly pre-commit to their setting of $Q$ and $X$. This may be a strong assumption. Byrd (1992, p. 321) documented in a case study that Anshan, a steel maker, complained about delayed announcement of plan targets. If the official cannot credibly pre-commit, it may be appropriate to assume that the two parties move simultaneously. But this change doesn't alter the model's testable predictions.

${ }^{8}$ Profit maximization may be a simplistic description of the firm's objective. But what matters here is that the firm doesn't ignore the profit incentive introduced by the reforms (Li, 1997) in making decisions.
} 
to raise price. And since neither $X, p$, nor $m$ affect the firm's marginal revenue or marginal cost, the optimal $P$ should not be affected by $X, p$ or $m$. The comparative statics results are summarized in the third column in Table 2.

Anticipating the firm's pricing decision $P(Q, M, W)$, the output official sets $Q$ to maximize $R_{O}$ by equating the marginal benefit and the marginal cost from diversion. The equilibrium is depicted in Panel B, Figure 2. ${ }^{9}$ In choosing $Q$, the output official takes into account the anticipated decrease in $P$ as he increases $Q$, as if he faces a downward sloping demand curve for the diverted good. As in Shleifer and Vishny (1993), an increase in $p$ raises the marginal cost of diversion and therefore reduces $Q$. However, $m$ has no effect on $Q$ when diversion of output and input quotas are done independently by different officials. Unlike Shleifer and Vishny (1993), the marginal cost of production may matter here because of the potential competition between the official and the firm. An increase in the marginal cost of production forces the producer to raise output price. This in turn increases the marginal benefit of diversion and thus induces the output official to increase the output quota for the purpose of diversion. The optimal output quota $Q(p, M, W)$ is thus expected to decrease in $p$, and increase in $M$ and $W$, as summarized in Column 4, Table 2.

While the firm, as a buyer, takes $M$ as given, the input official may have market power as a seller in the input market. The input official's problem is thus analytically identical to that of the output official. By analogy, $Q^{*}$ and hence $X=\left(1-\delta^{*}\right) Q^{*}$ should decrease with $m$ and increase with the marginal cost of producing the input, or $M^{*}$ and $W^{*}$. The optimal input quota allocated to the firm can be written as $X\left(m, M^{*}, W^{*}\right)$. The comparative statics results for $X$ are listed in Column 5 in Table 2.

\section{Empirical Evidence}

To test the derived implications using the available firm-level panel data described in the Appendix, I first discuss the selection of econometric specifications. I then present and analyze the empirical results.

A. Econometric methods. Consider first the specification under the hypothesis that sellers have market power. As discussed, structural relations that determine firm $n$ 's $(\log )$

\footnotetext{
${ }^{9}$ Since the official cannot impose a negative output quota, he faces the constraint $Q \geq 0$. Panel B in Figure 2 characterizes an interior equilibrium where $Q>0$. But if the official cannot profitably set $Q>0$, he would set $Q=0$ if $\left.P\right|_{Q=0}<p+\left.C_{O}^{\prime}\right|_{Q=0}$. Factors that decrease $Q$ in an interior equilibrium are thus the ones that raise the likelihood of a boundary equilibrium.
} 
market price in year $t, \ln P_{n t}$, and output quota, $Q_{n t}$, can be expressed as

$$
\begin{aligned}
\ln P_{n t} & =\alpha_{Q} Q_{n t}+\alpha_{X} X_{n t}+\alpha_{W} \ln W_{n t}+\alpha_{M} \ln M_{n t}+\epsilon_{n t}^{\prime} \\
Q_{n t} & =\beta_{p} \ln p_{n t}+\beta_{W} \ln W_{n t}+\beta_{M} \ln M_{n t}+\beta_{m} \ln m_{n t}+\xi_{n t}^{\prime}
\end{aligned}
$$

where $W_{n t}, M_{n t}, p_{n t}$ and $m_{n t}$ are, respectively, the base wage rate, the market price of input, the plan prices of output and input that firm $n$ faces in year $t$; and $\epsilon_{n t}^{\prime}$ and $\xi_{n t}^{\prime}$ are random errors (not necessarily of mean zero). The included regressors are exogenous to the output official and the firm. Similarly, the input quote equation can be written as

$$
X_{n t}=\gamma_{p} \ln p_{n t}+\gamma_{W} \ln W_{n t}+\gamma_{m} \ln m_{n t}+\eta_{n t}^{\prime}
$$

where the included variables are exogenous to the input official, and $\eta_{n t}^{\prime}$ represents a random error. The empirical task is to estimate these equations and test the theoretical predictions as summarized in Table 2 .

As they stand, the equations are not estimable due to the following data limitations. First, while price indexes are available, price levels are unobserved (see the Appendix). In addition, genuine market prices did not exist before 1985, and the implicit market prices were unobservable. Second, the observed output and input quotas are censored since a significant number of firms reported zero output or input quotas (see the Appendix). And finally, two variables that affect $X_{n t}$ - the base wage rate $W_{n t}^{*}$ and the market input price $M_{n t}^{*}$ that firm $n$ 's input suppliers face - are unobserved and hence omitted from (5). Below I address the econometric issues imposed by the data limitations on each equation and outline an estimable specification.

1. The output quota equation. The theory implies that censored output quota observations can be written as $Q_{n t}=\max \left\{Q_{n t}^{0}, 0\right\}$, where $Q_{n t}^{0}$ is the latent output quota expressed in (4) (see footnote 9 ). By substituting in the observed price indexes, $p_{n t}^{i} \equiv p_{n t} / p_{n, 80}, M_{n t}^{i} \equiv M_{n t} / M_{n, 80}$, and $m_{n t}^{i} \equiv m_{n t} / m_{n, 80}$, one obtains a fixed-effects Tobit specification,

$$
Q_{n t}=\max \left\{\beta_{p} \ln p_{n t}^{i}+\beta_{W} \ln W_{n t}+\beta_{M} \ln M_{n t}^{i}+\beta_{m} \ln m_{n t}^{i}+\mu_{n}^{q}+\nu_{t}^{q}+\xi_{n t}, 0\right\}
$$

where $\mu_{n}^{q}$, after absorbing $\beta_{p} \ln p_{n, 80}+\beta_{M} \ln M_{n, 80}+\beta_{m} \ln m_{n, 80}$, represents the firm-specific effects, $\nu_{t}^{q}$ the time-specific effects, and $\xi_{n t}$ the idiosyncratic error. In general, $\mu_{n}^{q}$ also captures the effects on $Q_{n t}$ of unobserved firm-specific factors such as time-invariant product characteristics and official-firm relationships, while $\nu_{t}^{q}$ captures the effects of unobserved macroeconomic 
factors that affect all firms, such as inflation and nationwide anti-corruption campaigns. Given the available data, (6) can be estimated consistently using Honoré's (1992) semi-parametric method for fixed-effects Tobit models.

2. The input quota equation. Similarly, (5) can be specified as a fixed-effects Tobit model,

$$
X_{n t}=\max \left\{\gamma_{p} \ln p_{n t}^{i}+\gamma_{W} \ln W_{n t}+\gamma_{m} \ln m_{n t}^{i}+\mu_{n}^{x}+\nu_{t}^{x}+\eta_{n t}, 0\right\}
$$

where $\mu_{n}^{x}$ and $\nu_{t}^{x}$ are the firm-specific and time-specific effects, and $\eta_{n t}$ is the idiosyncratic error. Honoré's (1992) Tobit can be applied to (7), but the estimates may be contaminated by omitted variables. Conditional on the fixed effects, the error term $\eta_{n t}$ may contain certain idiosyncratic components of the omitted variables, $\ln W_{n t}^{*}$ and $\ln M_{n t}^{*}$. Since changes in the base wage rate are often coordinated by the central government, it is likely that $\ln W_{n t}$ is positively correlated with $\ln W_{n t}^{*}$. It is also possible that $\ln m_{n t}^{i}$ is positively correlated with $\ln M_{n t}^{*}$ and $\ln W_{n t}^{*}$, if changes in the plan price of the input producer's output follow changes in its production cost. As a result, estimates of the coefficients on $\ln m_{n t}^{i}$ and $\ln W_{n t}$ are likely biased upward. But these biases cannot be ascertained without additional data.

3. The pricing equation for $t \geq 1985$. Since market prices did not exist before 1985 , the pricing equation is estimable for the post-liberalization period. I apply a first-order difference on both sides of (3) to eliminate the firm-specific effects. Let $\Delta$ denote the first difference operator such that $\Delta \ln P_{n t}^{i}=\ln P_{n t}^{i}-\ln P_{n, t-1}^{i}$. This transformation yields,

$$
\Delta \ln P_{n t}^{i}=\alpha_{Q} \Delta Q_{n t}+\alpha_{X} \Delta X_{n t}+\alpha_{W} \Delta \ln W_{n t}+\alpha_{M} \Delta \ln M_{n t}^{i}+\nu_{t}^{p}+\epsilon_{n t}
$$

OLS estimates of (8) are likely biased since $\Delta Q_{n t}$ and $\Delta X_{n t}$ are themselves endogenous. For one, $\Delta Q_{n t}$ is likely positively correlated with $\epsilon_{n t}$ : an upward shift in the market demand for the output that increases $\epsilon_{n t}$ and hence $P_{n t}$ should induce the output official to raise $Q_{n t}$. To estimate (8) consistently, I use the Generalized Method of Moments (GMM, Hansen (1982)) with these instrumental variables: $\Delta \ln p_{n t}^{i}, \Delta \ln m_{n t}^{i}, \Delta \ln M_{n t}^{i}, \Delta \ln W_{n t}$, a constant, and year dummies. These variables should be correlated with the regressors in (8) but not with the idiosyncratic error $\epsilon_{n t}$. The GMM estimates are consistent and asymptotically normal.

Equations (6)-(8) are specified under the hypothesis of imperfect competition. But they can be readily adapted for the case where product markets are perfectly competitive. As discussed in Section 3, the hypothesis of perfect competition requires including $\ln P_{n t}^{i}$ in (6) 
and $\ln P_{n t}^{i}$ and $\ln M_{n t}^{i}$ in (7) as additional regressors, and dropping (8) as the market price is exogenous to the firm. Given that the implications of perfect competition and imperfect competition are different (see Table 2), the null hypothesis of perfect competition can be easily tested against the alternative joint hypothesis of imperfect competition.

B. Empirical results. Table 3 reports four sets of estimates of the output quota equation (6) using fixed-effects Tobit. The time-specific effects, estimated by including year dummies in the regression, are not reported here. The first three columns present two sets of estimates under the hypothesis that sellers have market power in the product markets. Column 1 reports estimates obtained under the restriction that equation coefficients are time invariant. This restriction is relaxed for estimates in Columns 2 and 3 to allow coefficients to differ before and after the price liberalization in January 1985. Columns 4 to 6 report the same two sets of estimates under the hypothesis of perfect competition, where an additional regressor, "log market output price," is included in the regression. Table 4 reports the same four sets of estimates for the input quota equation (7) using fixed-effects Tobit. The output quota regressions use 7038 observations, while the input quota regressions use 4434 observations, reflecting the fact that the input quota variable has a larger number of missing observations.

Inspection of the signs of the estimated coefficients in the first three columns of Tables 3 and 4 reveals that all variables operate more or less as predicted under the hypothesis of imperfect competition (see Columns 4 and 5, Table 2). Focus first on the estimates in Table 3. "Log plan output price" increases corrupt officials' marginal cost of diversion. It should reduce the amount of output quota that the official procures and diverts. The estimated negative coefficients on this variable confirm this prediction. "Log market input price" and "log base wage rate" both increase the marginal cost of production that the firm faces, and should raise the market price of output for any given output quota. Since the resulting upward shift in the market price increases the marginal benefit from diverting output quota, the official should have a strong incentive to raise the output quota. As expected, the estimated coefficients on both variables are positive and statistically significant. There is a negative but (statistically) insignificant effect of the plan price of input on output quota. This is consistent with the assumption that output and input quotas are diverted independently by different officials.

Turn next to the estimates of the input quota equation (7) in Table 4 under the hypothesis of imperfect competition. As discussed, the estimates may be affected by omitted-variables biases. In particular, the estimates of the coefficients on $\ln W_{n t}$ and $\ln m_{n t}^{i}$ may be biased upward. Since $\ln W_{n t}$ is expected to have no effect on $X_{n t}$, an upward bias here should be 
easily observable if it is present. Table 4 shows that the biases appear to be concentrated in the second half of the 1980s. As predicted, the estimates of the coefficient on $\ln m_{n t}^{i}$ are negative and statistically significant. This suggests that the expected upward biases in these estimates are too small to alter the qualitative effect of $\ln m_{n t}^{i}$ on $X_{n t}$.

But the upward biases may still have non-negligible quantitative effects. Inspection of Tables 3 and 4 shows that the estimates of the marginal effect of $\ln m_{n t}^{i}$ on $X_{n t}$ are much smaller in magnitude than the estimates of the marginal effect of $\ln p_{n t}$ on $Q_{n t}$. Part of the difference may be the biases that reduce the magnitude of the estimated marginal effect of $\ln m_{n t}^{i}$ on $X_{n t}$. But even in the absence of omitted-variables biases, the marginal effect of the plan price on the input quota $X_{n t}$ should be less than that on output quota $Q_{n t}$ since $X_{n t}$ represents only a portion $\left(1-\delta^{*}\right)$ of the amount $\left(Q^{*}\right)$ procured from the input producer. Without additional data, however, it is not possible to ascertain the size of the biases.

In contrast, inspection of the estimates in the last three columns of Table 3 reveals that most of the variables do not operate as predicted under the hypothesis of perfect competition. Theoretically, an increase in $\ln P_{n t}^{i}$ raises the marginal benefit of diversion. Holding everything else constant, this should increase $Q_{n t}$. Estimates of the coefficient on $\ln P_{n t}^{i}$, however, are negative and statistically insignificant at the $5 \%$ level. Estimates of the remaining coefficients are qualitatively similar to those in Columns 1-3, even though in theory they should be different. ${ }^{10}$ Inspection of the estimates in the last three columns of Table 4 also reveals that most of the variables do not operate as predicted under the hypothesis of perfect competition. Theoretically, an increase in $M_{n t}^{i}$ or a decrease in $m_{n t}^{i}$ raises the net marginal benefit of input diversion. Holding everything else constant, either change should increase $X_{n t}$. But estimates of the coefficient on $\ln M_{n t}^{i}$ are negative and statistically significant, while those on $\ln m_{n t}^{i}$ are insignificant. The inconsistencies between theory and empirics under perfect competition provide strong evidence against the hypothesis of perfect competition. They suggest that the market prices should be treated as endogenous variables. In the discussion below, I maintain the hypothesis that sellers have market power in product markets.

The evidence is also inconsistent with the implications of perfect collusion between the official and the firm. As discussed in Section 3, if the official and the firm collude perfectly in diversion, $Q_{n t}$ should not be affected by $M_{n t}$ or $W_{n t}$. The data contradict this prediction, suggesting that there perhaps are sufficient conflicts of interest between the official and the

\footnotetext{
${ }^{10}$ For example, under perfect competition, both $M_{n t}^{i}$ and $W_{n t}$ should have negligible impact on $Q_{n t}$.
} 
firm. In particular, given the evidence, the firm may face sufficiently strong profit incentives, so sharing some diversion proceeds may not alter its behavior qualitatively.

To what extent did the effects of corruption on resource allocation change as a result of market price liberalization in 1985? Inspection of the estimates before and after the liberalization as reported in Columns 2 and 3 in Table 3 shows that there is little qualitative change in how the output quota responds to changes in the included variables. Inspection of the estimates in Columns 2 and 3 in Table 4 would probably lead to the same conclusion when the omitted-variable biases are taken into account. The results reveal strikingly that even before the full implementation of the dual-track system, the allocation of in-plan resources is consistent with the hypothesis of corruption. They suggest that official diversion thrived even in the absence of a functioning product market, and that corrupt officials could have relied on implicit or black-market prices in making allocation decisions before prices were liberalized.

But there are quantitative differences in the estimated coefficients. The estimated marginal effect of the plan price on output quota is stronger before price liberalization: a one percentage point increase in the plan price would reduce the output quota by 73,000 yuan in the 1980-84 period and by 56,600 yuan in the 1985-89 period. The estimated effects of $\ln M_{n t}^{i}$ and $\ln W_{n t}$ on $Q_{n t}$ are stronger after the liberalization. A one percentage point increase in the market input price would increase output quota by 37,400 yuan in the 1980-84 period and by 42,000 yuan in the 1985-89 period. The increase between the two periods in the marginal effect of $\ln W_{n t}$ on $Q_{n t}$ is even stronger-from 11,500 yuan per one percentage point increase in $\ln W_{n t}$ to 65,500 yuan. Wald tests, conducted separately for each coefficient pair, rejected at $5 \%$ significant level only the hypothesis that the coefficient on $\ln W_{n t}$ is identical before and after the liberalization. The post-liberalization decrease in the estimated marginal effect of the plan price on output quota is not statistically significant. The increase in the response of output quota to changes in the base wage rate, and less statistically significantly in the market price of input, is probably due to the increased product market competition in the 1980s (Li, 1997). As increased competition squeezes a firm's profit margin tighter, an increase in the marginal cost of production will likely be passed through more fully to customers in the form of higher output prices. This in turn would induce an increase in output quota.

To analyze the effect of competition more directly, I turn now to the GMM estimates of output pricing equation (8) for the post-liberalization period. The results are reported in Table 5. Since allowing the firm to sell directly to customers introduces competition between the firm and the official, the output quota imposed on the firm should have a negative effect on 
the market price. The estimated coefficient on $\Delta Q_{n t}$ is negative and statistically significant, confirming the predicted effect of competition between the firm and the official. Also expected, the estimated coefficient on $\Delta X_{n t}$ is positive but statistically significantly, again consistent with the assumption that output and input quotas are diverted independently by different officials. The estimates of the coefficients on $\ln M_{n t}^{i}$ and $\ln W_{n t}$ are all positive as predicted, but they are not as precisely estimated as to be statistically significant at the $5 \%$ level.

In theory, one should be able to improve the precision of the GMM estimates by increasing the sample size. Since $X_{n t}$ has more missing observations than $Q_{n t}$, the sample size in the GMM regression can be raised significantly if $\Delta X_{n t}$, which in theory should be excluded, is dropped from the regression. The GMM estimates with $\Delta X_{n t}$ excluded are reported in Column 2. Excluding $\Delta X_{n t}$ increases the number of observations from 2261 to 3655 and the $t$-ratios of the estimates markedly. But it reduces the size of the estimated coefficient on $\Delta \ln M_{n t}^{i}$. This is not surprising. Given that the estimate of the coefficient on $\Delta X_{n t}$ is positive and that by symmetry an increase in $X_{n t}$ should decrease $\ln M_{n t}^{i}$, excluding $\Delta X_{n t}$ is expected to reduce the estimate on the coefficient of $\Delta \ln M_{n t}^{i}$.

In sum, the evidence shows that the allocation of both in-plan and outside-plan resources between 1980 and 1989 in China exhibits strong empirical patterns, and that these patterns support the joint hypothesis of official diversion and imperfectly competitive product markets.

\section{Conclusion}

Exploiting a unique data set containing detailed transactions data from a panel of 769 Chinese state-owned enterprises, this paper tests microeconomic implications of corruption-official diversion of in-plan industrial goods - on resource allocation. It finds that corruption has a significant impact on the allocation of both in-plan and outside-plan resources under the dual-track system in China in ways consistent with the predictions of an extended version of Shleifer and Vishny's (1993) model of corruption. Regression analysis of the determination of in-plan quotas reveals that a decrease in the plan price-part of the marginal cost that the corrupt official faces - increases the procurement of goods into the plan for the purpose of diversion. It also reveals that an increase in the marginal cost of production that a firm faces, which raises the market price of its product and hence the marginal benefit from diverting the product, will induce the official to raise the procurement quota on the product for purposes

of diversion. Interestingly, the evidence shows that there is little qualitative difference in how 
diversion affected the allocation of in-plan resources before and after the price liberalization in 1985. The evidence thus suggests that corruption existed before 1985, and that corrupt officials made diversion decisions based on the implicit prices embodied in favors and in-kind bribes. An important implication of this finding is that the introduction of the market track in China per se did not cause corruption. The culprit was China's reliance on planning, which gave government officials the control over resource allocation and therefore the institutional incentive to be corrupt (see Rose-Ackerman (1999) for a general discussion).

But the Chinese reform may still have changed the nature of official diversion. On the one hand, by allowing firms to sell their products directly to customers (and by lowering the entry barriers for non-state firms), the reform introduced market competition and reduced the market power of corrupt officials. Regression analysis of the market pricing equation reveals that the introduction of market competition, ceteris paribus, resulted in lower market prices and hence lower corruption distortions. On the other habd, by creating markets and hence monetizing corruption, the reform may have reduced the transaction costs of corruption and therefore helped spread corruption. In addition, the widening of the gap between market and plan prices as documented in Table 1 would certainly have also encouraged official diversion. The net effect could well be increased pervasiveness of corruption in the late 1980s.

The evidence here reveals that the dual-track system, in spite of its desirable properties (e.g., Li, 1999; Lau, Qian and Roland, 2000), had a serious downside: it maintained the plan that was the source of official diversion. This particular corruption turned out to be transitional. As product markets gradually replaced the plan in allocating industrial products in the late 1990s, official diversion of industrial products gradually faded away. But anecdotal evidence suggests that corrupt officials in China have found greener pastures elsewhere (e.g., the financial sector where governmental control remains strong, see Huang (1996)). 


\section{References}

Byrd, W. A. (1992). Chinese Industrial Firms under Reform, Oxford University Press, Oxford.

Hansen, L. P. (1982). Large sample properties of generalized method of moments estimators, Econometrica 50: 1029-1054.

Honoré, B. E. (1992). Trimmed LAD and least squares estimation of truncated and censored regression models with fixed effects, Econometrica 60: 533-565.

Huang, W. (1996). Zhongguo de Yingxing Jingji (The Hidden Economy in China), Commercial Publishing House, Beijing.

Lau, L., Qian, Y. and Roland, G. (2000). Reform without losers: An interpretation of China's dual-track approach to transition, Journal of Political Economy .

Li, W. (1994). Essays on the Economics of Transition, PhD thesis, University of Michigan.

Li, W. (1997). The impact of economic reform on the performance of Chinese state enterprises, 1980-1989, Journal of Political Economy 105(5): 1080-1106.

Li, W. (1999). A tale of two reforms, Rand Journal of Economics 30: 120-136.

Li, W. (2001). Measuring corruption: An indirect approach using Chinese enterprise survey data. University of Virginia, Darden School of Business.

Mauro, P. (1995). Corruption and growth, Quarterly Journal of Economics 110: 681-712.

Rose-Ackerman, S. (1998). Corruption and development, in B. Pleskovic and J. E. Stiglitz (eds), Annual World Bank Conference on Development Economics 1997, The World Bank, Washington, DC, pp. 35-57.

Rose-Ackerman, S. (1999). Corruption and Government: Causes, Consequences, and Reform, Cambridge University Press, Cambridge; New York and Melbourne.

Shleifer, A. and Vishny, R. W. (1993). Corruption, Quarterly Journal of Economics 108: 599617.

Transparency International (2000). Corruption perception index. http://www. transparency . org/, Otto-Suhr-Allee 97/99, 10585 Berlin, Germany. 
Wei, S.-J. (2000). How taxing is corruption on international investors?, Review of Economics and Statistics LXXXII: $1-11$. 


\section{A Appendix}

The data come from a survey of 769 Chinese state-owned enterprises. Annual data between 1980 and 1989 are collected retrospectively. The sample covers a diverse selection of stateowned firms. Located in four provinces (Jiangsu, Jilin, Shanxi, and Sichuan), these firms represent 36 (out of a total of 40) two-digit industries in mining, logging, utilities, and manufacturing. The data contain rich information on each firm's participation in the dual-track system, giving details on the plan and the market prices (as chained indexes) that each firm faced as well as the amounts of outputs and inputs transacted at these prices. Below I give a brief description of the available price and quantity index variables. Details on how these variables are constructed can be found in $\mathrm{Li}$ (1997).

\section{A. Price indexes and wage rate}

Detailed data on price indexes (or inflation rates) and the ratios of market to plan prices in each firm for each firm are collected in the survey. The data allow the construction of indexes of market prices of output, $P_{n t}^{i} \equiv P_{n t} / P_{n, 80}$, market prices of material inputs, $M_{n t}^{i} \equiv M_{n t} / M_{n, 80}$, plan prices of output, $p_{n t}^{i} \equiv p_{n t} / p_{n, 80}$, and plan prices of material inputs, $m_{n t}^{i} \equiv m_{n t} / m_{n, 80}$, for each firm $n$. Here $P_{n, 80}, M_{n, 80}, p_{n, 80}$ and $m_{n, 80}$ denote the firm-specific base-year (1980) prices, which are unobserved. The base wage rate, $W_{n t}$, is measured as the base wage per worker in year $t$.

Note that the "market prices" before the price liberalization in January 1985 were "floating prices" and remained under price control. The weighted average annual rates of market price inflation and the gaps between market prices and plan prices for both output and material inputs are reported in Table 1.

\section{B. Output quota and input quota}

For each firm, real output quota $Q_{n t}$ and real input quota $X_{n t}$, measured in 1989 market prices, ${ }^{11}$ are available. Zero output quota accounts for $22 \%$ of all observations between 1980 and 1989 for which output quota is not missing, while zero input quota accounts for $49 \%$ of all observations for which input quota is not missing. These statistics suggest that at any given time more firms were required to sell their output at plan prices than were given inputs at plan prices. Furthermore, as Table 1 shows, the proportion of output sold at market prices was lower than the proportion of input bought at market prices in each year in the sample.

\footnotetext{
${ }^{11}$ Since market prices in 1989 — the last year in the sample — were presumably less distortionary than either plan prices or market prices in earlier years, all quantity variables are measured in 1989 market prices to make them comparable both over time and across firms.
} 


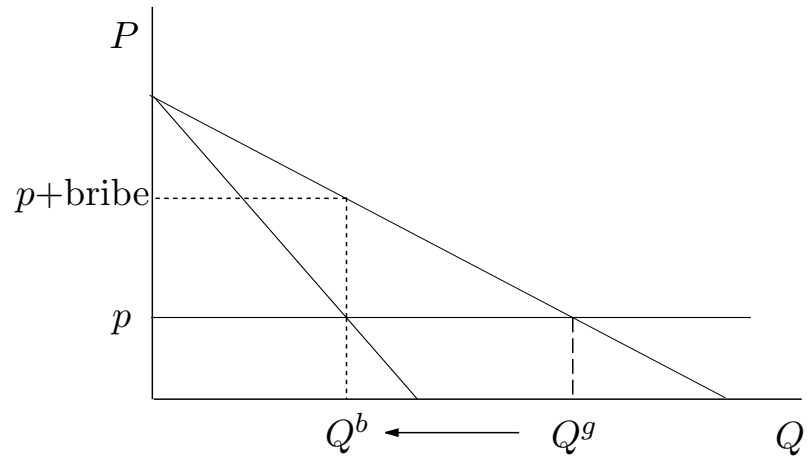

Figure 1: Shleifer and Vishny's (1993) model of corruption. The official, acting as a bribemaximizing monopolist, restricts the supply of a government-produced good from $Q^{g}$ to $Q^{b}$.

A. Eq. Price $P(Q, M, W)$

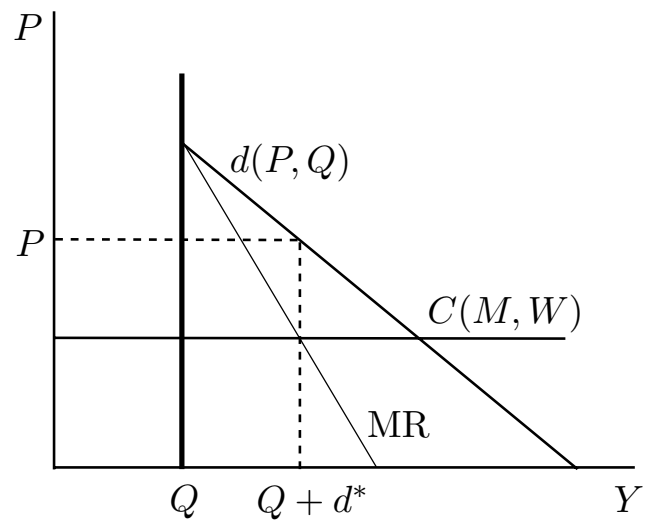

B. Eq. Output Quota $Q(p, M, W)$

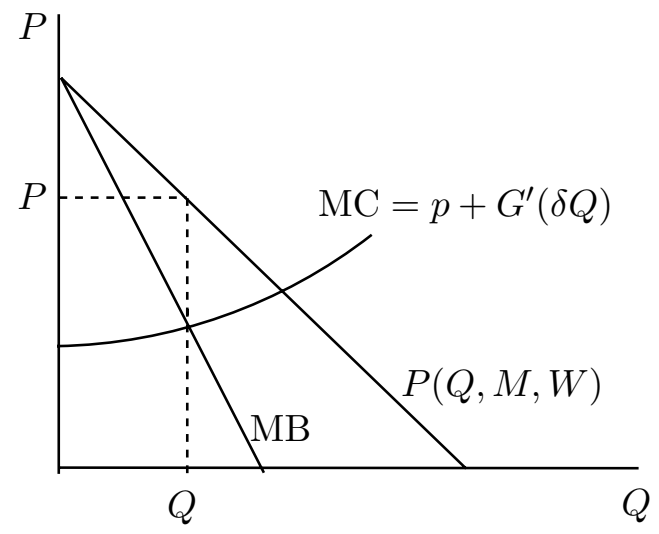

Figure 2: Equilibrium solution to the two-stage game between the firm and the official. Panel A shows the determination of the firm's optimal market pricing for any given $Q$ and $X$. Panel B shows the determination of output quota, $Q$, as the official maximizes diversion rents anticipating the firm's pricing decision. 
Table 1: Dual-track system as seen from a sample of state-owned enterprises covering 36 2-digit industries.

\begin{tabular}{|c|c|c|c|c|c|c|c|c|}
\hline & \multicolumn{4}{|c|}{ Output } & \multicolumn{4}{|c|}{ Material Inputs } \\
\hline Year & $\begin{array}{l}\text { Market* } \\
\text { price } \\
\text { inflation }\end{array}$ & $\frac{\text { market } P}{\text { plan } P}$ b & $\begin{array}{l}\text { Percent } \\
\text { sold to } \\
\text { market }^{\mathrm{c}}\end{array}$ & $\begin{array}{l}\text { Output } \\
\text { quota } \\
\text { per firm }\end{array}$ & $\begin{array}{l}\text { Market* } \\
\text { price } \\
\text { inflation }\end{array}$ & $\frac{\text { market } P}{\text { plan } P}$ & $\begin{array}{c}\text { Percent } \\
\text { bought from } \\
\text { market }^{g}\end{array}$ & $\begin{array}{l}\text { Input } \\
\text { quota } \\
\text { per firm }\end{array}$ \\
\hline 1981 & $0.6 \%$ & 1.03 & $26.0 \%$ & 32.2 & $1.3 \%$ & 1.22 & $27.5 \%$ & 16.0 \\
\hline 1982 & $2.4 \%$ & 1.05 & $27.5 \%$ & 30.4 & $1.0 \%$ & 1.16 & $29.7 \%$ & 16.8 \\
\hline 1983 & $2.2 \%$ & 1.04 & $25.8 \%$ & 32.0 & $2.0 \%$ & 1.31 & $27.5 \%$ & 21.5 \\
\hline 1984 & $3.2 \%$ & 1.06 & $25.7 \%$ & 33.9 & $7.1 \%$ & 1.24 & $32.2 \%$ & 20.4 \\
\hline 1985 & $7.3 \%$ & 1.16 & $26.4 \%$ & 36.2 & $5.2 \%$ & 1.30 & $39.4 \%$ & 20.6 \\
\hline 1986 & $9.3 \%$ & 1.26 & $24.9 \%$ & 37.7 & $19.0 \%$ & 1.41 & $44.7 \%$ & 17.4 \\
\hline 1987 & $4.6 \%$ & 1.17 & $25.1 \%$ & 45.6 & $11.9 \%$ & 1.63 & $50.0 \%$ & 17.1 \\
\hline 1988 & $22.0 \%$ & 1.16 & $25.9 \%$ & 45.2 & $39.6 \%$ & 1.84 & $56.5 \%$ & 14.1 \\
\hline 1989 & $21.2 \%$ & 1.39 & $25.0 \%$ & 44.2 & $18.7 \%$ & 2.17 & $56.4 \%$ & 14.1 \\
\hline
\end{tabular}

* Prior to 1985, market prices were measured as "floating" prices, which remained under price control. By excluding possible in-kind payoffs and the costs of queuing, "floating" prices perhaps underestimated the implicit market-clearing prices.

a Percentage change in market prices from the previous year, weighted by sales measured in market prices.

b Weighted by sales measured in plan prices.

c Weighted by sales measured in market prices.

d Million yuan, measured in 1989 market prices.

e Percentage change in market prices from the previous year, weighted by input purchases measured in market prices.

f Weighted by input purchases measured in plan prices.

$\mathrm{g}$ Weighted by input purchases measured in market prices. 
Table 2: Comparative statics results.

\begin{tabular}{c|cc|ccc}
\hline & \multicolumn{2}{|c|}{ Perfect competition } & \multicolumn{3}{c}{ Imperfect competition } \\
\hline & Effect on $Q$ & Effect on $X$ & Effect on $P$ & Effect on $Q$ & Effect on $X$ \\
\hline$Q$ & NA & NA & - & NA & NA \\
$X$ & NA & NA & 0 & NA & NA \\
\hline$P$ & + & 0 & NA & NA & NA \\
$p$ & - & 0 & 0 & - & 0 \\
\hline$M$ & 0 & + & + & $+^{1}$ & NA \\
$m$ & 0 & - & 0 & 0 & - \\
\hline$W$ & 0 & 0 & + & $+^{1}$ & 0 \\
$M^{*}$ & NA & 0 & NA & NA & $+{ }^{1}$ \\
$W^{*}$ & NA & 0 & NA & NA & $+^{1}$ \\
\hline
\end{tabular}

$\mathrm{NA}=$ not applicable.

${ }^{1}$ Under the assumption that the marginal benefit of diversion, $\mathrm{MB}=P+Q \partial P / \partial Q$, is increasing in $M$ and $W$. 
Table 3: Estimation of the output quota equation (6) using Honoré's semi-parametric fixedeffects Tobit. The dependent variables, $Q_{n t}$, are measured in 1989 market prices in 10 million yuan. For specifications under the hypothesis of perfectly competitive product markets, an additional regressor, "log market output price" is added. The time-specific effects, estimated by including year dummies in the regression, are not reported below. Estimation and hypothesis testing are done using Pantob, a library of GAUSS routines provided by Bo Honoré. The estimator uses the absolute value loss function. The numbers reported in parentheses are $t$-ratios (asymptotically normal statistics).

\begin{tabular}{l|c|cc|c|cc}
\hline & \multicolumn{2}{|c|}{ Imperfectly competitive mkts } & \multicolumn{3}{c}{ Perfectly competitive mkts } \\
\cline { 2 - 7 } & $1980-89$ & $1980-84$ & $1985-89$ & $1980-89$ & $1980-84$ & $1985-89$ \\
\hline Log market output price, ln $P_{n t}^{i}$ & & & & -0.157 & -0.319 & -0.107 \\
& & & & $(-1.227)$ & $(-1.539)$ & $(-0.887)$ \\
Log plan output price, $\ln p_{n t}^{i}$ & -0.534 & -0.730 & -0.566 & -0.421 & -0.430 & -0.472 \\
& $(-4.821)$ & $(-6.968)$ & $(-5.087)$ & $(-3.248)$ & $(-2.327)$ & $(-4.080)$ \\
Log market input price, $\ln M_{n t}^{i}$ & 0.419 & 0.374 & 0.420 & 0.489 & 0.515 & 0.444 \\
& $(3.676)$ & $(3.103)$ & $(3.740)$ & $(4.321)$ & $(4.113)$ & $(3.822)$ \\
Log plan input price, $\ln m_{n t}^{i}$ & -0.175 & -0.053 & -0.157 & -0.199 & -0.147 & -0.125 \\
& $(-1.686)$ & $(-0.466)$ & $(-1.376)$ & $(-1.944)$ & $(-1.336)$ & $(-1.153)$ \\
Log base wage rate, $\ln W_{n t}$ & 0.395 & 0.115 & 0.655 & 0.396 & -0.091 & 0.610 \\
& $(4.986)$ & $(1.390)$ & $(4.702)$ & $(5.021)$ & $(-0.869)$ & $(4.594)$ \\
\hline Observations [\% censored] & \multicolumn{7}{|c}{$7086[22 \%]$} \\
\hline
\end{tabular}


Table 4: Estimation of the input quota equation (7) using Honoré's semi-parametric fixedeffects Tobit. The dependent variable, $X_{n t}$, is measured in 1989 market prices in 10 million yuan. For specifications under the hypothesis of perfectly competitive product markets, two additional regressors, "log market output price" and "log market input price" are added. The time-specific effects, estimated by including year dummies in the regression, are not reported below. Estimation and hypothesis testing are done using Pantob, a library of GAUSS routines provided by Bo Honoré. The estimator uses the absolute value loss function. The numbers reported in parentheses are $t$-ratios (asymptotically normal statistics).

\begin{tabular}{l|c|cc|c|cc}
\hline & \multicolumn{2}{|c|}{ Imperfectly competitive mkts } & \multicolumn{2}{c}{ Perfectly competitive mkts } \\
\cline { 2 - 7 } & $1980-89$ & $1980-84$ & $1985-89$ & $1980-89$ & $1980-84$ & $1985-89$ \\
\hline Log market output price, $\ln P_{n t}^{i}$ & & & & 0.131 & -0.099 & 0.077 \\
& & & & $(2.032)$ & $(-0.661)$ & $(1.141)$ \\
Log plan output price, $\ln p_{n t}^{i}$ & 0.048 & 0.096 & 0.048 & -0.062 & 0.225 & -0.022 \\
& $(0.985)$ & $(1.572)$ & $(0.912)$ & $(-1.073)$ & $(1.585)$ & $(-0.343)$ \\
Log market input price, $\ln M_{n t}^{i}$ & & & & -0.225 & -0.158 & -0.224 \\
& & & & $(-2.725)$ & $(-2.246)$ & $(-2.418)$ \\
Log plan input price, $\ln m_{n t}^{i}$ & -0.186 & -0.159 & -0.187 & -0.014 & -0.060 & -0.024 \\
& $(-3.384)$ & $(-2.889)$ & $(-3.313)$ & $(-0.165)$ & $(-0.682)$ & $(-0.261)$ \\
Log base wage rate, $\ln W_{n t}$ & 0.027 & -0.035 & 0.194 & 0.037 & -0.059 & 0.212 \\
& $(0.582)$ & $(-0.613)$ & $(2.900)$ & $(0.825)$ & $(-1.110)$ & $(3.245)$ \\
\hline Observations [\% censored] & \multicolumn{5}{|c}{4434} & {$[49 \%]$} \\
\hline
\end{tabular}


Table 5: GMM estimation of the output pricing equation (8) between 1985 and 1989. The dependent variable is the year-on-year change in the logarithm of market output price index, $\Delta \ln P_{n t}^{i}$. Not reported here are time-specific effects, which are estimated by including year dummies in each regression. Instrumental variables for GMM estimation are a constant, year dummies, and four exogenous variables $\left(\Delta \ln M_{n t}^{i}, \Delta \ln W_{n t}, \Delta \ln p_{n t}^{i}\right.$, and $\left.\Delta \ln m_{n t}^{i}\right)$.

\begin{tabular}{ccc}
\hline Year-on-year change in & & \\
Output quota, $\Delta Q_{n t}$ & -0.292 & -0.289 \\
& $(-3.13)$ & $(-4.87)$ \\
Input quota, $\Delta X_{n t}$ & 0.420 & \\
& $(1.03)$ & \\
Log market input price, $\Delta \ln M_{n t}^{i}$ & 0.634 & 0.151 \\
& $(1.38)$ & $(1.76)$ \\
Log base wage rate, $\Delta \ln W_{n t}$ & 0.206 & 0.220 \\
& $(1.16)$ & $(2.41)$ \\
Intercept & 0.090 & 0.118 \\
& $(1.03)$ & $(3.774)$ \\
Year dummies & Yes & Yes \\
Number of observations & 2261 & 3655 \\
\hline
\end{tabular}




\section{DAVIDSON INSTITUTE WORKING PAPER SERIES - Most Recent Papers}

The entire Working Paper Series is available at: www.wdi.bus.umich.edu

CURRENT AS OF 10/30/01

\begin{tabular}{|c|c|c|}
\hline Publication & Authors & Date \\
\hline No. 396: Corruption and Resource Allocation: Evidence from China & Wei Li & June 2001 \\
\hline $\begin{array}{l}\text { No. 395: Government Shareholding and the Value of China's Modern } \\
\text { Firms }\end{array}$ & Lihui Tian & Apr. 2001 \\
\hline No. 394: Labor Hoarding in Russia: Where Does it Come from? & $\begin{array}{l}\text { Rouslan Koumakhov amd Boris } \\
\text { Najman }\end{array}$ & June 2000 \\
\hline $\begin{array}{l}\text { No. 393: Ownership Structure, Corporate Governance, And Firm Value: } \\
\text { Evidence from the East Asian Financial Crisis }\end{array}$ & Michael Lemmons and Karl Lins & Apr. 2001 \\
\hline No. 392: Marshall and Labour Demand in Russia: Going Back to Basics & $\begin{array}{l}\text { Jozef Konings and Hartmut } \\
\text { Lehmann }\end{array}$ & Aug. 2001 \\
\hline No. 391: Economic Transition and Elections in Poland & $\begin{array}{l}\text { John E. Jackson, Jacek Klich, and } \\
\text { Krystyna Poznańska }\end{array}$ & June 2001 \\
\hline $\begin{array}{l}\text { No. 390: Effects of Bank Insolvency and Strategic Uncertainty on } \\
\text { Corporate Restructuring in Transition Economies }\end{array}$ & Christa Hainz & Aug. 2001 \\
\hline No. 389: Mark-Up Pricing In Bulgarian Manufacturing & $\begin{array}{l}\text { Rumen Dobrinsky, Boyko } \\
\text { Nikolov, and Nikolay Markov }\end{array}$ & June 2001 \\
\hline $\begin{array}{l}\text { No. } 388 \text { Globalization and Firms' Financing Choices: } \\
\text { Evidence from Emerging Economies }\end{array}$ & $\begin{array}{l}\text { Sergio Schmukler and Esteban } \\
\text { Vesperoni }\end{array}$ & May 2001 \\
\hline $\begin{array}{l}\text { No. } 387 \text { The Distributional Impacts of Indonesia's Financial Crisis on } \\
\text { Household Welfare: A "Rapid Response" Methodology }\end{array}$ & $\begin{array}{l}\text { Jed Friedman and James } \\
\text { Levinsohn }\end{array}$ & Sept. 2001 \\
\hline $\begin{array}{l}\text { No. } 386 \text { Corporate Financial Policies and Performance Prior to Currency } \\
\text { Crises }\end{array}$ & $\begin{array}{l}\text { Arturo Bris, Yrjö Koskinen, and } \\
\text { Vicente Pons }\end{array}$ & June 2001 \\
\hline No. 385 Ownership and Productive Efficiency: Evidence from Estonia & Derek C. Jones and Niels Mygind & Aug. 2001 \\
\hline $\begin{array}{l}\text { No. } 384 \text { Forthcoming in: Journal of Economic Perspectives, } \\
\text { "Institutional Determinants of Labor Reallocation in Transition" Vol. } \\
\text { 16, No. 2, Feb. } 2002 \text {. }\end{array}$ & Tito Boeri and Katherine Terrell & June 2001 \\
\hline $\begin{array}{l}\text { No. } 383 \text { Deindustrialisation and Structural Change During the Post- } \\
\text { Communist Transition }\end{array}$ & $\begin{array}{l}\text { Tomasz Mickiewicz and Anna } \\
\text { Zalewska }\end{array}$ & June 2001 \\
\hline No. 382 Markets and Growth & Štěpán Jurajda and Janet Mitchell & July 2001 \\
\hline $\begin{array}{l}\text { No. } 381 \text { Labor Market Discrimination During Post-Communist } \\
\text { Transition: A Monopsony Approach to the Status of Latvia's Russian } \\
\text { Minority }\end{array}$ & Robert S. Chase & Sept. 2000 \\
\hline No. 380 Dollarization of Liabilities in Non-tradable Goods Sector & Frédéric Chabellard & June 2001 \\
\hline $\begin{array}{l}\text { No. } 379 \text { Lessons from the Russian Meltdown: The Economics of Soft } \\
\text { Legal Constraints }\end{array}$ & Enrico Perotti & Mar. 2001 \\
\hline No. 378 Effective Tax Rates in Transition & Vlad Ivanenko & May 2001 \\
\hline $\begin{array}{l}\text { No. } 377 \text { Some Explanations for Changes in the Distribution of } \\
\text { Household Income in Slovakia: } 1988 \text { and } 1996\end{array}$ & $\begin{array}{l}\text { Thesia Garner and Katherine } \\
\text { Terrell }\end{array}$ & May 2001 \\
\hline $\begin{array}{l}\text { No. } 376 \text { Competition and Enterprise Performance in Transition } \\
\text { Economies: Evidence from a Cross-country Survey }\end{array}$ & $\begin{array}{l}\text { Wendy Carlin, Steven Fries, } \\
\text { Mark Schaffer and Paul Seabright }\end{array}$ & May 2001 \\
\hline $\begin{array}{l}\text { No. } 375 \text { Why More is Actually Less: New Interpretations of China's } \\
\text { Labor-Intensive FDI }\end{array}$ & Yasheng Huang & May 2001 \\
\hline No. 374 Economic Fragmentation and FDI in China & Yasheng Huang & May 2001 \\
\hline $\begin{array}{l}\text { No. } 373 \text { Earnings Disparities in the Czech Republic: Evidence of the } \\
\text { Past Decade and Cross-National Comparison }\end{array}$ & Jiri Vecernik & May 2001 \\
\hline $\begin{array}{l}\text { No. } 372 \text { Economic Reform, Democracy and Growth During Post- } \\
\text { Communist Transition }\end{array}$ & Jan Fidrmuc & Mar. 2001 \\
\hline $\begin{array}{l}\text { No. } 371 \text { Do Multinational Enterprises Substitute Parent Jobs for Foreign } \\
\text { Ones? Evidence from Firm Level Panel Data }\end{array}$ & Jozef Konings and Alan Murphye & Apr. 2001 \\
\hline $\begin{array}{l}\text { No. } 370 \text { From Needs to the Market: Changing Inequality of Household } \\
\text { Income in the Czech Transition }\end{array}$ & Jiri Vecernik & Apr. 2001 \\
\hline
\end{tabular}

